\title{
Career preferences among final year medical students and house officers: A multicentre survey in Southwest Nigeria
}

\author{
*Idowu A.O. ${ }^{1,2}$, Oyebisi O.O. ${ }^{3}$, Ehioghae O. ${ }^{2}$, Ijiomah E. ${ }^{2}$, Adesegun O.A. ${ }^{1}$, \\ Ogunkoya J.O. ${ }^{2,4}$, Osibowale B. ${ }^{1}$, Osonuga A. ${ }^{1}$, Idowu A.A. ${ }^{5}$, Bamidele F. ${ }^{6}$
}

\begin{abstract}
Objective: Career preferences of medical trainees have the potential to shape the future of the healthcare workforce of any nation. This study aimed to determine the factors that influence career choices of medical students and house officers (interns) in two institutions located in Southwest Nigeria.
\end{abstract}

Methods: A cross-sectional study was carried out amongst final year medical students and interns in two medical universities and their corresponding teaching hospitals in Southwest Nigeria. A questionnaire was used to obtain socio-demographic data, career choices, reasons behind career choices and the presence and influence of mentorship on career choices. Responses were analyzed using the Statistical Package for Social Sciences Version 21, and descriptive statistics generated.

Results: Obstetrics \& Gynecology and Surgical specialties were the most preferred career choices by the medical students, while Surgical and Medical specialties were most preferred by the interns. Personal interest and other personal reasons were the top motivating factors for the career choices amongst the medical students of both institutions, while personal interest and future job opportunities were the top reasons for the career choices amongst the interns of both institutions. Mentorship was lacking for most of the medical students and house officers, except in one of the teaching hospitals, where over half of the interns had career mentors.

Conclusion: Attention should be paid to the reasons behind career choices, in order to channel efforts towards making clinical specialties become attractive to young medical trainees, as the future of the health workforce in the nation depends on it.

Keywords: Career Choices, Medical Students, House officers, Medical Education, Nigeria

*Correspondence author

Idowu A.O.

http://orcid.org/0000-0003-2902-958X

Email address: kolamed2002@yahoo.com

${ }^{1}$ Endocrinology, Diabetes and Metabolism Unit, Department of Internal Medicine, Babcock University Teaching Hospital, Ilishan-Remo, Nigeria.

${ }^{2}$ Benjamin S. Carson (Snr.) School of Medicine, Babcock University, Ilishan-Remo, Nigeria.

${ }^{3}$ Olabisi Onabanjo University Teaching Hospital, Sagamu, Nigeria

${ }^{4}$ Pulmonology Unit, Department of Internal Medicine, Babcock University Teaching Hospital, Ilishan-Remo, Nigeria.

${ }^{5}$ Department of Pharmacy, Babcock University Teaching Hospital, Ilishan-Remo, Nigeria.

${ }^{6}$ Department of Community Medicine, Babcock University Teaching Hospital, Ilishan-Remo, Nigeria.

Research Journal of Health Sciences subscribed to terms and conditions of Open Access publication. Articles are distributed under the terms of Creative Commons Licence (CC BY-NC-ND 4.0). (http://creativecommons.org/licences/by-nc-nd/4.0).

http://dx.doi.org/10.4314/rejhs.v8i1.5 


\title{
Préférences de carrière chez les étudiants en médecine et les agents de maison : une enquête multi-centre dans le sud-ouest du Nigéria
}

\author{
*Idowu A.O. ${ }^{1,2}$, Oyebisi O.O. ${ }^{3}$, Ehioghae O. ${ }^{2}$, Ijiomah E. ${ }^{2}$, Adesegun O.A. ${ }^{1}$, \\ Ogunkoya J.O. ${ }^{2,4}$, Osibowale B. ${ }^{1}$, Osonuga A. ${ }^{1}$, Idowu A.A. ${ }^{5}$, Bamidele F. ${ }^{6}$
}

\begin{abstract}
Résumé
Objectif: Préférences des étudiants en médecine ont le potentiel de façonner l'avenir de la main - d'œuvre de la santé de toute nation. To déterminer les facteurs que les choix de carrière d'influence des étudiants en médecine et maison des officiers ( stagiaires) dans deux établissements situés dans sud - ouest du Nigéria.
\end{abstract}

Méthodes: Une étude transversale a été menée auprès d'étudiants en médecine de dernière année et de stagiaires dans deux universités de médecine et leurs hôpitaux d'enseignement correspondants dans le sud-ouest du Nigéria. Un questionnaire a été utilisé pour obtenir des données sociodémographiques, choix de carrière, raisons des choix de carrière et la présence et l'influence du mentorat sur les choix de carrière. Les réponses ont été analysées à l'aide du progiciel statistique pour les sciences sociales, version 21, et des statistiques descriptives ont été générées.

Résultats: Les spécialités d'obstétrique et de gynécologie et de chirurgie étaient les choix de carrière les plus privilégiés par les étudiants en médecine, tandis que les spécialités de chirurgie et de médecine étaient les plus préférées par les stagiaires. L'intérêt personnel et d'autres raisons personnelles ont été les principaux facteurs de motivation pour les choix de carrière des étudiants en médecine des deux établissements, tandis que l'intérêt personnel et les perspectives d'emploi futures ont été les principales raisons des choix de carrière des stagiaires des deux établissements. Le mentorat faisait défaut pour la plupart des étudiants en médecine et des officiers de maison, sauf dans l'un des hôpitaux d'enseignement, où plus de la moitié des stagiaires avaient des mentors de carrière.

Conclusion: Une attention particulière devrait être accordée aux raisons des choix de carrière, afin de canaliser les efforts à faire de spécialités cliniques deviennent attrayants pour les jeunes étudiants en médecine, comme l'avenir de la main - d'œuvre de la santé dans la nation en dépend.

Mots - clés : Choix de carrière, étudiants en médecine, officiers de maison, éducation médicale, Nigéria

*Auteur correspondant

Idowu A.O.

http://orcid.org/0000-0003-2902-958X

Email address:kolamed2002@yahoo.com

'Endocrinology, Diabetes and Metabolism Unit, Department of Internal Medicine, Babcock University Teaching Hospital, Ilishan-Remo, Nigeria.

${ }^{2}$ Benjamin S. Carson (Snr.) School of Medicine, Babcock University, Ilishan-Remo, Nigeria.

${ }^{3}$ Olabisi Onabanjo University Teaching Hospital, Sagamu, Nigeria

${ }^{4}$ Pulmonology Unit, Department of Internal Medicine, Babcock University Teaching Hospital, Ilishan-Remo, Nigeria.

${ }^{5}$ Department of Pharmacy, Babcock University Teaching Hospital, Ilishan-Remo, Nigeria.

${ }^{6}$ Department of Community Medicine, Babcock University Teaching Hospital, Ilishan-Remo, Nigeria. 


\section{INTRODUCTION}

Nigeria, with a population of over 200 million people is the most populous country in Africa, comprising a rich and diverse sociocultural sphere (1). The country currently has 34 fully accredited medical schools for the undergraduate training of medical doctors (2). Inbetween medical school and specialty training, is a one-year internship period, known as housemanship, where the medical graduate rotates through and practices under supervision in the four core specialties - Obstetrics and Gynecology, Pediatrics, Internal Medicine and Surgery. This period serves as a time to consolidate theoretical knowledge with practical skills, and often culminates in a career choice, specialty training or otherwise.

Commencing specialist training at postgraduate level is something most medical students look forward to. In the USA, from the $3^{\text {rd }}$ and $4^{\text {th }}$ year, medical students decide what specialty they prefer, and they look forward to "match". Result of the match is published, and patterns of specialty preference discussed by the National Resident Matching Program. Though other countries may not have a complex matching algorithm like the United states, most have exams for each specialty that doctors take, depending on their interest. In the West African sub-region, there are two institutions for post-graduate (specialty) training of doctors namely the West African Postgraduate Medical College and the National Postgraduate Medical College of Nigeria $(3,4)$. Each college requires prospective trainees to pass a test known as the "Primaries", to be eligible for training.

Amongst the various challenges faced in Nigeria is the paucity of medical doctors and specialists, despite the high number of training institutions. According to the World Health Organization, a doctor-patient ratio of 23/10,000 is recommended for satisfactory health care delivery (5). In Nigeria however, this ratio is $4 / 10,000$ (6). A lack of understanding of the career choice-patterns of medical students could make it difficult for policies to be made that favor training in particular specialties, and this can potentiate the brain-drain and efflux of doctors from the country.

Although studies have been conducted in the past which concentrated on areas such as characteristics of individuals choosing particular careers, factors that influence career choices among medical students in different settings, there is still dearth of data from the Southwestern part of the country, where a high number of the medical schools in Nigeria can be found.

It is of significance therefore, that we study factors that influence career preferences of medical students and interns, as the future of the country's healthcare workforce can be determined by the choices made by them and understanding the determinants may just be the panacea to the current dearth of medical doctors in the country. It is expected that the findings will add to the pool of knowledge concerning the current career preferences and determinants of medical students and house officers, and hence provide additional information needed for policy makers in the development and fortification of the healthcare workforce and post-graduate medical training in Nigeria and West Africa.

The aim of the study was to describe the factors affecting career preferences of final year medical students and medical graduates in their internship training (house officers).

The objectives were to assess the career preferences among final year medical students and house officers of two universities in Southwest Nigeria and their corresponding teaching hospitals, to determine the factors that influence career preferences among said groups, to determine the presence and influence of mentorship on career preferences and to describe the similarities and/or differences between the responses of medical students when compared with the house officers.

\section{MATERIALS AND METHODS Study Area}

The study was carried out in two medical schools, the Benjamin S. Carson (Snr.) School of Medicine, Babcock University (BU), and the Obafemi Awolowo College of Health Sciences, Olabisi Onabanjo University (OOU) and their respective teaching hospitals - Babcock University Teaching Hospital (BUTH) and Olabisi Onabanjo University Teaching Hospital (OOUTH). Both institutions are in Ogun State, in the Southwestern part of Nigeria and are noted for excellence in undergraduate and postgraduate medical training, as well as service delivery in a wide variety of specialties.

\section{Study Setting}

Both medical schools run pre-medical, pre-clinical and clinical undergraduate training, as well as housemanship and residency training on the postgraduate front. Pre-medical courses include Physics, Chemistry, Biology, and Mathematics, taken in the first year. Successful students then proceed to pre-clinical training in 
Anatomy, Physiology and Biochemistry, for the second and third year. Clinical training starts in the fourth year with pathology and pharmacology, along with the clinical specialties - Obstetrics and Gynecology, Medicine, Surgery, Pediatrics, Psychiatry, Community Medicine and Family Medicine.

The postgraduate arm features training of successful medical graduates (interns) in the four major clinical specialties - Medicine, Surgery, Obstetrics and Gynecology, Paediatrics, after which interested candidates may proceed for residency training in chosen fields after passing the primary examination for either the West African College of Physician/Surgeons or the National Postgraduate Medical College of Nigeria. At the time of the study, there were 42 and 49 final year medical students in BU and OOU respectively, while there were 11 and 28 house officers in BUTH and OOUTH respectively.

\section{Study Design}

The study was a questionnaire-based, cross-sectional survey of final year students and house officers of the above-mentioned institutions, carried out in January 2019.

The sample population consisted of final year medical students and house officers in the aforementioned institutions. Individuals who refused to participate in the study were excluded. All the final year medical students and house officers were eligible to participate in the study.

A structured self-administered questionnaire was used to obtain data. The questionnaire took about 10-15 minutes to complete and consisted of questions which assessed:

1. Socio-demographic data

2. Choice of specialty

3. Reasons for selected choices.

4. The presence and influence of mentorship on career choices

The questionnaire was constructed after a careful and detailed review of existing literature related to this study.

Data obtained was analyzed using the Statistical Package for Social Sciences (SPSS) Version 21, and descriptive statistics were generated.

Ethical Considerations: Ethical approval was obtained from the Babcock University Health Research Ethics Committee (BUHREC), with registration number BUHREC215/19. The purpose and need for the study was explained to the participants, and their consent obtained. No identifying information was collected. Participation was voluntary and willing participants were not coerced to participate.

\section{RESULTS}

A total of 130 individuals participated in this study - 49 medical students from OOU, 42 medical students from BU, 28 house officers from OOUTH and 11 house officers from BUTH.

\section{Analysis of Data from the Medical Students}

More than half of the medical students from OOU were males $(53.1 \%)$, and the mean and modal ages were $26.61 \pm 3.6$ years and 25 years respectively. In contrast, most of the medical students from BU (73.8\%) were females, with the mean and modal ages being $22.14 \pm 1.4$ years and 22 years respectively (See Table 1). Concerning the choice of post-graduate career path, most of the medical students from OOU preferred one or more specialty training fields, while some others preferred non-medical career paths. Obstetrics and Gynecology (28.6\%) was the most preferred specialty among these respondents. Medical (16.3\%) and surgical $(12.2 \%)$ specialties were the next most preferred, followed by pediatrics $(10.2 \%)$. Worthy of note are the non-medical career paths chosen by some respondents from OOU. Two respondents preferred to become car dealers, one preferred to join the armed forces, one preferred medical law, one politics, and one respondent preferred "none". On the other hand, all the medical students from BU were interested in pursuing post-graduate specialty training, save for two individuals who were yet undecided. Surgical specialties $(33.3 \%)$ were the most preferred amongst BU medical students, followed by Pediatrics $(28.6 \%)$ and medical specialties $(11.9 \%)$ (See Table 2). Personal interest and other personal reasons were the top motivating factors for the career choices amongst $\mathrm{OOU}$ and $\mathrm{BU}$ medical students, followed by future job opportunities, lifestyle and financial reward and influence of a mentor (See Fig. 1).

Less than half of the medical students from OOU (40.8\%) had a mentor, but majority of them that had mentors admitted to having their career choices influenced by their mentor in one way or another; $85.7 \%$ of all of the medical students from OOU were interested in assuming mentorship roles to other young colleagues in the future. Similarly, amongst the medical students from $\mathrm{BU}$, only $28.6 \%$ admitted to having a mentor. However, most of them that had a mentor also admitted to having their career choices influenced by their mentor. Nearly all the medical students from BU (98\%) declared interest in being mentors to younger colleagues in the 
future. Both medical students from OOU and BU admitted that the top values that they obtained from their mentors included general guidance and career counseling. Age and gender had no significant relationship to career choice $(\mathrm{p}>$ 0.05). Having a career mentor also had no significant relationship to the interest in mentorship in the future, for any of the student groups $(\mathrm{p}>0.05)$.

\section{Analysis of Data from the House Officers}

Over half $(60.7 \%)$ of the house officers from OOUTH were male, with the mean and modal ages being $27 \pm 2.4$ years and 25 years respectively. Similarly, most of the house officers from BUTH were male $(63.6 \%)$, with the mean and modal ages being $25.9 \pm 4.7$ years and 25 years respectively. BUTH had more international medical graduates (IMGs) than OOUTH (See Table 1). All house officers from OOUTH and BUTH had specialty career preferences, the most preferred being surgical specialties (39.3\%), followed by Obstetrics and Gynecology $(27.3 \%)$ among OOUTH house officers. On the other hand, BUTH house officers preferred medical specialties more (45.4\%), followed by Obstetrics and Gynecology (27.3\%) (See Table 3). Personal interest, previous positive clerkship/rotation experience, future job opportunities and influence of a mentor were the top reasons for the career choices amongst OOUTH and BUTH house officers (See Fig. 1). Over half of the house officers from OOUTH (53.6\%) admitted to having a mentor while in medical school, and acknowledged the significant influence of their mentor on their career choices. However, nearly all $(92.3 \%)$ of the house officers from OOUTH who had no mentor believed that they would have benefitted from one. In contrast, nine out of eleven house officers from BUTH (81.2\%) had no career mentor while in medical school, and most of them believed they would have benefitted from one. However, all those who did have a career mentor attested to the strong influence their mentor had on their career choices. Majority of the house officers from OOUTH $(85.7 \%)$ and BUTH $(90.9 \%)$ were interested in taking up mentorship roles to younger colleagues in the future. Some of the top values obtained from mentors by house officers from OOUTH and BUTH include general guidance, career counseling and assistance and support surrounding professional issues. Age and gender had no significant relationship with career choices $(p>0.05)$, neither did having a career mentor have any significant relationship to the interest in mentorship in the future, for any of the house officer groups $(\mathrm{p}>0.05)$.

\section{DISCUSSION}

We described the career choices of medical students and house officers in public and private medical training institutions in Nigeria, giving an insight into the pattern of a yet unexamined cohort of students and interns. The mean age of the medical students was noted to be higher in OOU, a finding also noted among the OOUTH house officers, who were also older than their counterparts in private institutions (table 1). Typically, the duration of undergraduate medical education in Nigeria is 6 years, and the age of enrolment is often between 16 and 20 years especially in private institutions (7). However, delays in tertiary education due to industrial action of teachers and ancillary staff, as well as delay in accreditation of some medical programs are common in the Nigerian tertiary education system. These factors may contribute to the age disparity observed in our study (see table 1). These delays can have deleterious effects on students' learning and academic performance and has been shown to favor educational tourism to other African and European countries (8).

Surgery/Surgical specialties and Obstetrics and Gynecology were the top picks of both medical student groups, followed closely by Pediatrics and Medical specialties. Surgical disciplines as well as Obstetrics and Gynecology have remained the favorite choice amongst medical students in Nigeria, as corroborated by previous studies across various regions of the country (9-11). The preference for Obstetrics and Gynecology as well as the surgical specialty seems to persist even after graduation from medical school, to the internship period as observed amongst OOUTH house officers in the study and this has been corroborated by other researchers (12). This may be due to the hands-on nature of both specialties, and the potential for high remuneration which are characteristic of these practices in Nigeria (more so in private practice), in addition to other factors such as personal interest and mentor influences. Similar reports have been obtained in other African medical schools (13).

General practice (or family medicine), which was selected by few of our respondents, is a favored career choice in Europe (14,15). In a particular study, it was noted that both medical students and house officers preferred general practice, more so after a clinical attachment in the department, because of the "better lifestyle and work hours in general practice" and a "dislike for hospital work". This also shows that career 
choices are dynamic and can change with time and exposure to the field in question (15). The above findings are in contrast with our study and other African reports, possibly because the role of family medicine in the health sector is still poorly understood and harnessed in Africa (16-17). The roles of the general practitioner in developed countries is pivotal to the health sector, as the general practitioner is the first point of call for health care, and often continues care even when patients have returned from seeking tertiary care (18). Internal medicine seems to be favored in Asia and Southeast Asia, as reported by studies from Japan, India and Pakistan (19-21), especially due to personal interest and the family friendly nature of the discipline among other reasons (19).

One factor that seems to be recurrent as a reason for career preferences in multiple studies, including the current study, is personal interest $(11,19,20)$. However other factors such as previous positive clerkship/rotation experience, future job opportunities and the lifestyle and financial rewards must not be overlooked. Efforts should be made to enhance the clinical experience in other specialties of need, especially while the students and house officers rotate through these departments.

Only few of the respondents in our study selected career choices outside the four core Specialties of Medicine. There are several other specialty choices such as Emergency medicine, Geriatric Medicine, Occupational Medicine, Academics (including Basic Science/Biomedical Research) to mention a few, that could benefit the health sector in Nigeria, which are often neglected due to the rudimentary state in which they are. Lack of exposure of students and house officers to these many varieties may limit their knowledge of, and interest in such specialties. There is need for government and policy makers to identify these other fields which could transform healthcare in Nigeria, and prioritize them by making policies geared at developing these areas, thus attracting young minds.

The poor state of mentorship noted in our study (both amongst the medical students and house officers) tells a negative story about the state of mentorship in the medical training system in Nigeria, and around the world where bullying in medical education is common (22-24). This may have been responsible for some of the nonmedical career paths such as Politics, joining the Armed forces and car dealing, selected by some respondents though a general lack of interest in pursuing a future in medicine could also have contributed to such responses. Those that did benefit from mentors in our study admitted to the positive role their mentors played in their lives, as regards their choice of a future career and their perception of mentorship in the future.

\section{CONCLUSION}

Career preferences are dynamic and can change with time and exposure to clinical practice. Other factors including mentorship, financial gains and future job prospects are also deciding factors. Clinicians and academics involved in curriculum development and appraisal need to be aware of students' and interns' needs, so as to provide an enabling environment for them to make the best career choices that would benefit themselves and the nation's healthcare workforce.

Conflict of interest: There are no conflicts of interest to disclose.

\section{REFERENCES}

1. Nigeria Overview. [Online] Available from: https://www.worldbank.org/en/country/nigeria/o verview [Accessed: 17th March 2020]

2. Medical and Dental Council of Nigeria. Status of Accredited Medical and Dental Schools in Nigeria. [Online] Available from: https:/www.mdcn.gov.ng/page/education/accre dited-medical-dental-schools-in-nigeria [Accessed: 10th July 2019]

3. National Postgraduate Medical College of Nigeria » Establishment and Functions. [Online] Available from: https://npmcn.edu.ng/aboutus/establishment-and-functions/ [Accessed: 10th July 2019]

4. West African College of Surgeons | College Objectives. [Online] Available from: http://www.wacscoac.org/index.php/aboutus/college-objectives [Accessed: 10th July 2019]

5. WHO | Achieving the health-related MDGs. It takes a workforce! WHO. [Online] World Health Organization; 2018; Available from: https:/www.who.int/hrh/workforce_mdgs/en/ [Accessed: 11th July 2019]

6. WHO. Nigeria: Progress report on the Kampala Declaration and Agenda for Global Action. 2012; A v a i l a b l e f r o m : https://www.who.int/workforcealliance/countrie s/Nigeria_En.pdf

7. Ademola EO, Ogundipe AT, Babatunde WT. (PDF) students' enrolment into tertiary institutions in nigeria: the influence of the founder's reputation - a case study. [Online] Computing, Information Systems, Development Informa tics \& Allied Research Journal A v a i 1 a b l e f $\mathrm{r}$ o m : https://www.researchgate.net/publication/27243 0614_STUDENTS'_ENROLMENT INTO_TE RTIARY_INSTITUTIONS_IN_NIGERIA_TH 
E INFLUENCE OF THE FOUNDER'S REP UTATION - A CASE STTUDY [Accessed: 12th June 2019]

8. Yusuf FA. Student's perception of Strike Actions on Academic Performance in Nigeria University: Implications for Best Practices and Counselling. SMCC Higher Education Research Journal. [Online] 2017;3(1): 1-6. Available from: doi:10.18868/sher3j.03.00117.09

9. Obarisiagbon OE, Owoeye G, Chukwu JC, Onwuchekwa V. Assessment of career specialty preferences among medical students at the University of Benin, Benin city, Edo state. Annals of Biomedical Sciences. [Online] Department of Child Health, University of Benin Teaching Hospital; 2002;17(1). Available from: https://www.ajol.info/index.php/abs/article/view /168960 [Accessed: 20th July 2019]

10. Onyeka T, Ewuzie N. Choice of Future Career amongst Medical Students in Enugu, Nigeria: Implications for Anaesthesia. Nigerian Journal of Surgery. [Online] 2011;16(1-2). Available from: doi:10.4314/njs.v16i1-2.70780 [Accessed: 21st July 2019]

11. C Onyemaechi N, Bisi-Onyemaechi A, Omoke N, Odetunde O, Okwesili I, Okwara B. Specialty choices: Patterns and determinants among medical undergraduates in Enugu Southeast Nigeria. Nigerian Journal of Clinical Practice. [Online] Medknow Publications and Media Pvt. Ltd.; 2017;20(11): 1474. Available from: doi:10.4103/njcp.njcp_382_16 [Accessed: 15th June 2019]

12. Okonta KE, Akpayak IC, Amusan EO, Ekpe EE, Adamu YB, Ocheli mmanuel O. Multi-center survey of House officers' choice of Medical specialties in Nigeria: preferences and determining factors. Pan African Medical Journal. [Online] 2015;20. Available from: doi: $10.11604 / \mathrm{pamj} .2015 .20 .338 .4113$ [Accessed: 21st July 2019]

13. Dossajee H, Obonyo N, Ahmed SM. Career preferences of final year medical students at a medical school in Kenya-A cross sectional study. BMC Medical Education. [Online] BioMed Central; 2016;16(1): 5. Available from: doi:10.1186/s12909-016-0528-1 [Accessed: 18th July 2019]

14. Soethout MBM, ten Cate OTJ. Career preferences among medical students. Nederlands tijdschrift voor geneeskunde. [Online] 2014;158: A6655. A v a i 1 a b 1 e $\mathrm{f} \mathrm{r}$ o $\mathrm{m}$ : http://www.ncbi.nlm.nih.gov/pubmed/24569047 [Accessed: 20th July 2019]

15. Morrison JM, Murray TS. Career preferences of medical students: influence of a new four-week attachment in general practice. The British journal of general practice: the journal of the Royal College of General Practitioners. [Online] Royal College of General Practitioners; 1996;46(413): 721-725. Available from: http://www.ncbi.nlm.nih.gov/pubmed/8995851 [Accessed: 21st July 2019]
16. Moosa S, Downing R, Mash B, Reid S, Pentz S, Essuman A. Understanding of family medicine in Africa: a qualitative study of leaders' views. The British journal of general practice : the journal of the Royal College of General Practitioners. [Online] Royal College of General Practitioners; 2013;63(608): e209-16. Available from: doi:10.3399/bjgp13X664261 [Accessed: 21st July 2019]

17. van der Voort CTM, van Kasteren G, Chege P, Dinant G-J. What challenges hamper Kenyan family physicians in pursuing their family medicine mandate? A qualitative study among family physicians and their colleagues. $B M C$ family practice. [Online] BioMed Central; 2012;13: 32. Available from: doi:10.1186/14712296-13-32 [Accessed: 21st July 2019]

18. Onion DK, Berrington RM. Comparisons of UK General Practice and US Family Practice. The Journal of the American Board of Family Medicine. [Online] 1999;12(2): 162-172. Available from: doi:10.3122/jabfm.12.2.162

19. Nasir S, Zahid U, Bhatti ZG. Post Graduate Career Preferences Among Medical Students. Journal of Rawalpindi Medical College Students Supplement. 2016;2016(2): 89-92.

20. Huda N, Yousuf S. Career preference of final year medical students of Ziauddin Medical University. Education for Health: Change in Learning \& Practice. [Online] 2006;19(3): 345-353. A v a i 1 a b l e f r o m : doi:10.1080/13576280600984087 [Accessed: 21 st July 2019]

21. Ie K, Murata A, Tahara M, Komiyama M, Ichikawa S, Takemura YC, et al. What determines medical students' career preference for general practice residency training?: a multicenter survey in Japan. Asia Pacific Family Medicine. [Online] BioMed Central; 2018;17(1): 2. Available from: doi:10.1186/s12930-018-0039-9 [Accessed: 21st July 2019]

22. Major A. To Bully and Be Bullied: Harassment and Mistreatment in Medical Education. AMA Journal of Ethics. [Online] American Medical Association; 2014;16(3): 155-160. Available

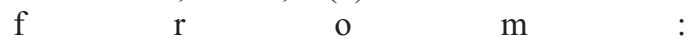
doi:10.1001/virtualmentor.2014.16.3.fred11403 [Accessed: 22nd July 2019]

23. Vogel L. Bullying still rife in medical training. CMAJ : Canadian Medical Association journal = journal de l'Association medicale canadienne. [Online] Canadian Medical Association; 2016;188(5): 321-322. Available from: doi:10.1503/cmaj.109-5237 [Accessed: 22nd July 2019]

24. Leisy HB, Ahmad M. Altering workplace attitudes for resident education (A.W.A.R.E.): discovering solutions for medical resident bullying through literature review. BMC Medical Education. [Online] 2016;16(1): 127. Available from: doi:10.1186/s12909-016-0639-8 [Accessed: 22nd July 2019 
Table 1: Socio-demographic parameters of the respondents

\begin{tabular}{|c|c|c|c|c|}
\hline Variable & $\begin{array}{l}\text { BMS } \\
\mathrm{N}=42(100 \%)\end{array}$ & $\begin{array}{l}\text { OMS } \\
N=49(100 \%)\end{array}$ & $\begin{array}{l}\text { BHO } \\
\mathrm{N}=11(100 \%)\end{array}$ & $\begin{array}{l}\text { OHO } \\
N=28(100 \%)\end{array}$ \\
\hline \multicolumn{5}{|l|}{ Age } \\
\hline Mean (years) & $22.14 \pm 1.4$ & $26.61 \pm 3.6$ & $25.9 \pm 4.7$ & $27 \pm 2.4$ \\
\hline \multicolumn{5}{|l|}{ Sex } \\
\hline Male & $11(26.2)$ & $26(53.1)$ & $7(63.6)$ & $17(60.7)$ \\
\hline Female & $31(73.8)$ & $23(46.9)$ & $4(36.4)$ & $11(39.3)$ \\
\hline Place & & & & \\
\hline \multicolumn{5}{|l|}{ Instruction } \\
\hline Nigerian trained & NA & NA & $5(45.5)$ & $23(82.1)$ \\
\hline -OOU & - & - & 0 & 14 \\
\hline$-B U$ & - & - & 3 & 1 \\
\hline -Other Nigerian & - & - & 2 & 8 \\
\hline \multicolumn{5}{|l|}{ Universities } \\
\hline IMG & NA & NA & $6(54.5)$ & $5(17.9)$ \\
\hline $\begin{array}{l}\text { BMS-Babcock Univ } \\
\text { OMS - Olabisi Onat } \\
\text { BHO-Babcock Uni } \\
\text { OHO - Olabisi Onat } \\
\text { IMG - International } \\
\text { NA - Not Applicable }\end{array}$ & $\begin{array}{l}\text { rsity Medical Stu } \\
\text { anjo University } \\
\text { ersity Teaching } \\
\text { anjo University } 1 \\
\text { Medical Graduat }\end{array}$ & $\begin{array}{l}\text { al Students } \\
\text { tal House Officers } \\
\text { ing Hospital Hous }\end{array}$ & icers & \\
\hline
\end{tabular}

Table 2: Career choices of medical students

\begin{tabular}{|c|c|c|c|}
\hline \multirow[b]{2}{*}{ Specialty choice } & \multicolumn{3}{|l|}{ Frequency $(\%)$} \\
\hline & $\begin{array}{l}\text { OOU } \quad \text { Medical } \\
(\mathrm{N}=49,100 \%)\end{array}$ & Students & $\begin{array}{l}\text { BU Medical Students } \\
(\mathrm{N}=42 ; 100 \%)\end{array}$ \\
\hline Obstetrics \& Gynecology & $14(28.6)$ & & $4(9.5)$ \\
\hline Pediatrics & $5(10.2)$ & & $12(28.6)$ \\
\hline Surgical Specialties* & $6(12.2)$ & & $14(33.3)$ \\
\hline Medical Specialties** & $8(16.3)$ & & $5(11.9)$ \\
\hline Radiology & $2(4.1)$ & & $1(2.4)$ \\
\hline $\begin{array}{l}\text { Public Health/ Community } \\
\text { Medicine }\end{array}$ & $2(4.1)$ & & $3(7.1)$ \\
\hline General Practice/Family Medicine & $1(2.0)$ & & $1(2.4)$ \\
\hline Pathology & $2(4.1)$ & & - \\
\hline Unsure & $2(4.1)$ & & $2(4.8)$ \\
\hline Others $* * *$ & $7(14.3)$ & & - \\
\hline
\end{tabular}

* Cardiothoracic Surgery, Cosmetic Surgery, General Surgery, Neurosurgery, Ophthalmology, Orthopaedics, Pediatric Surgery, Plastic Surgery, Urology

** Cardiology, Endocrinology, Internal Medicine, Interventional Cardiology, Neurology, Psychiatry *** Anaesthesia, Armed forces, Car dealing, Medical law, None, Politics 
Table 3: Career choices of the house officers

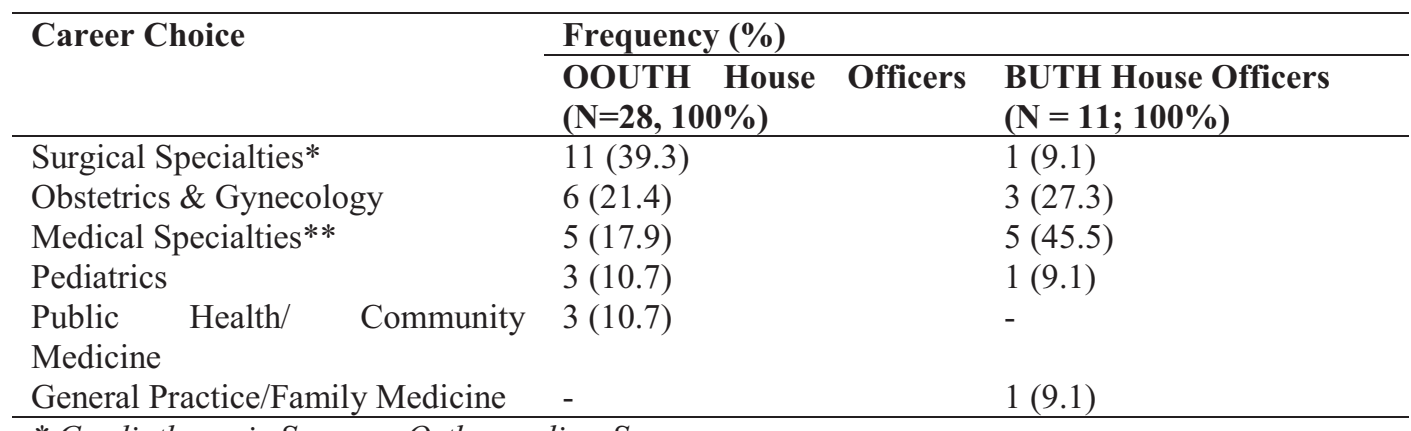

* Cardiothoracic Surgery, Orthopaedics, Surgery

** Cardiology/Cardiovascular medicine, Endocrinology, Internal Medicine

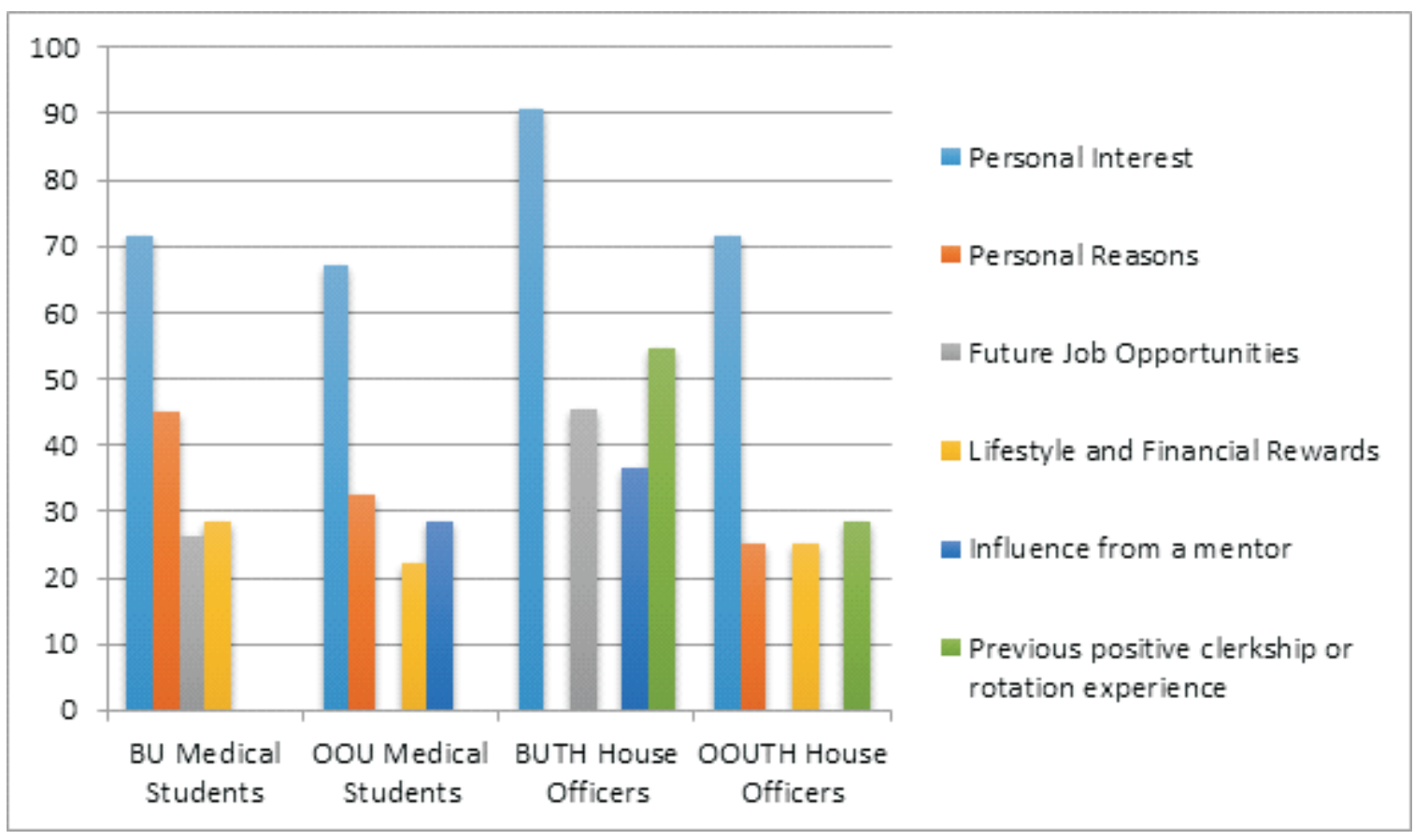

Footnote: The bars in the histogram represent the reasons for career choices and are displayed (as percentages of respondents) in decreasing order of rank from left to right BU-Babcock University; BUTH - Babcock University Teaching Hospital; OOU - Olabisi Onabanjo University; OOUTH - Olabisi Onabanjo University Teaching Hospital

Figure 1 Ranking of Reasons for Career Preferences 